\title{
Role of riverine sediment and particulate matter in adsorption of heavy metals
}

\author{
${ }^{I}$ M. Saeedi, ${ }^{2}$ Sh. Daneshvar and ${ }^{3 *} A$. R. Karbassi \\ ${ }^{I}$ Department of Civil Engineering, Iran University of Science and Technology, Tehran, Iran. \\ ${ }^{2}$ Department of Marine Chemistry, School of Marine Science and Technology, Islamic Azad University, Tehran, Iran. \\ ${ }^{3}$ Iran Energy Efficiency Organization, Tehran, Iran.
}

\begin{abstract}
Riverine sediments and suspended matters have been subjected to several bench scale tests for the evaluation of adsorption potential of heavy metals. For this purpose water, sediment and suspended particulate matters of Tadjan River (southern part of the Caspian Sea) were collected. In the vicinity of the river many polluting sources were recognized; for instance, pulp and paper mill, dairy factory and municipal sewage that can introduce various amounts of heavy metals into the river water. Bottom sediments and suspended particulate matters have been individually subjected to adsorption tests. The results of analysis showed that riverine bottom sediments have greater potential for adsorbing heavy metals than suspended matters. However the trend of adsorption in both sediments and suspended matters are similar. Maximum adsorption capacity of heavy metals (in terms of mg of metal per $\mathrm{kg}$ of sediments and suspended matters) by sediments and suspended matters are as: Sediments: $\mathrm{Cu}(2200)>\mathrm{Mn}(2000)>\mathrm{Ni}(1400)>\mathrm{Zn}(320)$

Suspended matters: $\mathrm{Cu}(2100)>\mathrm{Ni}(1500)>\mathrm{Mn}(1200)>\mathrm{Zn}(310)$

Further, results revealed that increasing concentration of metals would cause desorbing Cadmium from both sediments and suspended matters.
\end{abstract}

Key words: Adsorption, sediment, heavy metals, Tadjan River, Caspian Sea

*Corresponding Author, E-mail: Karbassi@iranenergy.org.ir

\section{Introduction}

Some parts of dissolved metals introducing into the rivers in contact with the particulate phase (sediments and suspended matters) adsorb on to the particles because of density of electrons on surface of the particles or probable chemical reactions (Zhou and Kot, 1995; Forstner, et al., 1981 and Chapman, 1992). The adsorption of dissolved metals on to the sediments and suspended particulate matters during mixing in rivers can significantly influence the chemical and physical forms of the metals and reduce the potential environmental risk of metals to organisms (Dojlido and Best, 1993). Many investigations have been carried out on adsorption of dissolved metals in rivers in relation with the role of physical and chemical parameters and finding adsorption patterns and isotherm equations (Benefield et al., 1982; Sholkovitz and Copland, 1981; Hart, 1982; Lin and Chen, 1998; Rose, 1989 and Zhou and Kot, 1995). However, not much information is available on the adsorption capacity and its relation to the concentration of dissolved metals. In an attempt to study adsorption of dissolved metals, a laboratory experiment on water, sediments and suspended matters samples rivers flowing into the Caspian Sea. There are many rivers flowing into the Caspian Sea via its southern coast through northern part of Iran that are ecologically of significant importance considering the Caspian Sea environment (e.g. Tadjan, SefidRud, Chaloos, Haraz, Babol, Talar, Tadjan and Gorganrud). Many of these rivers as well as Tadjan River are used as transport agents for the disposal of industrial, agricultural and urban wastes. Therefore, it is essential to closely investigate the processes affecting fate and behavior of metals in the rivers. In the present investigation capacity of dissolved metals adsorption by Tadjan River sediment and suspended matters was examined through a series of bench scale experiments.

\section{Materials and Methods}

River water, sediments and suspended matters were collected from the Tadjan River at a point that had not been affected by intrusion of saline water on 20 February 2001 (Figure 1). 


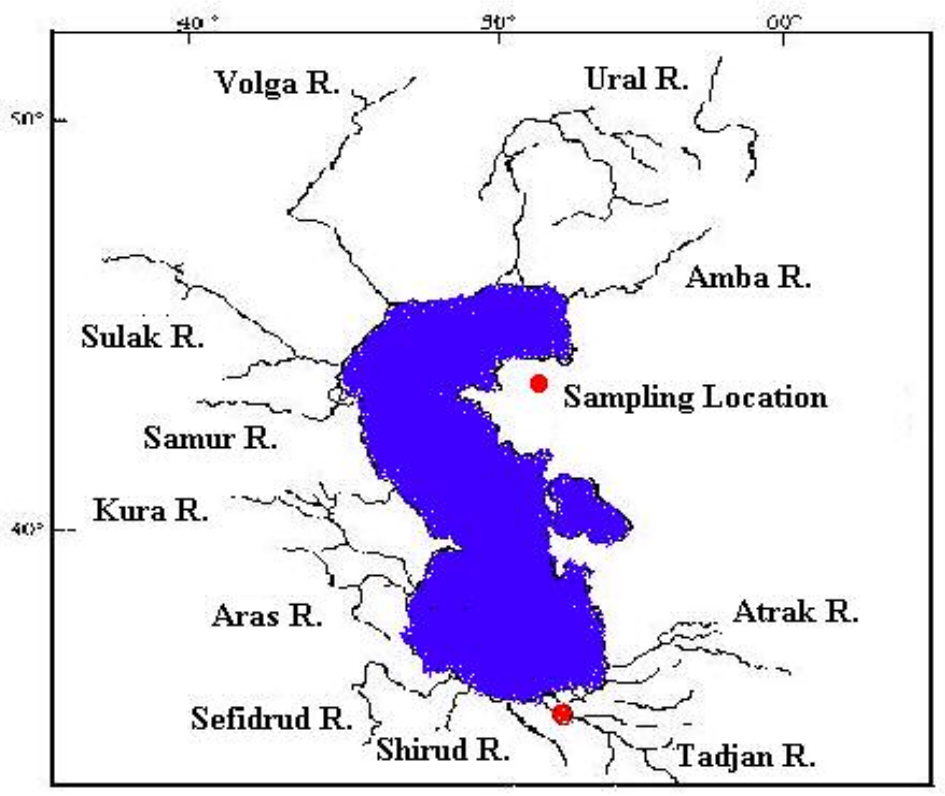

Figure 1: Map showing locations of sampling site

The water samples were filtered through $0.22 \mu \mathrm{m}$ Millipore AP and HA filter on the same day. Sediment and suspended matter samples were dried at $70^{\circ} \mathrm{C}$ for 24 hours (Karbassi, 1989).Adsorption experiments were conducted by adding appropriate amounts of heavy metals $(\mathrm{Mn}, \mathrm{Ni}, \mathrm{Cu}, \mathrm{Zn})$ to a constant volume of river water and sediment or suspended matter to obtain a series of mixtures of different concentrations of metals. In general, experiments were carried out under natural concentration of river water trace metals and also at 2.5, 5.0, 7.5 and $10 \mathrm{mg} / \mathrm{lit}$ concentrations. It should be pointed out that $5 \mathrm{gr}$ of sediment and SPM were used for each batch. Particulate samples were collected on $0.45 \mu \mathrm{m}$ Watt man filters and the concentrations of $\mathrm{Cu}, \mathrm{Mn}, \mathrm{Ni}, \mathrm{Zn}$ and $\mathrm{Cd}$ were determined flame atomic adsorption spectrometry technique. (U.S. EPA, 1990 and U.S. EPA, 1991). Procedural blanks and duplicates were run with the samples in a similar way. The accuracy of analysis was about $\pm 6 \%$ for all elements.

\section{Results}

Initial dissolved metal $(\mathrm{Cu}, \mathrm{Mn}, \mathrm{Ni}, \mathrm{Zn}$ and Cd) concentrations added to mixtures as well as the amount of metals adsorbed by sediments and suspended matters at various initial concentrations are presented in Table 1 and 2 respectively.

Also variations of adsorption capacity of sediments and suspended matters in relation to initial concentration of metals and equations of the adsorption capacity trends are presented in figures 2 and 3 for metals $\mathrm{Mn}, \mathrm{Zn}, \mathrm{Ni}$ and $\mathrm{Cu}$. According to the data shown in Tables 1 and 2 and Figures 2 and 3 amount of adsorption of metals by sediments and suspended matters increases with increasing of the initial concentration of metal in the river water but this trend merges to a constant value with a polynomial behavior.

Table 1: Heavy metals adsorption capacity of Tadjan River sediments in different concentration of metals in river water ( $\mathrm{mg}$ of metal $/ \mathrm{kg}$ of sediment)

\begin{tabular}{|cccccc|}
\hline $\begin{array}{c}\text { Initial metal concentration in } \\
\text { water }\end{array}$ & $\mathrm{Cu}$ & $\mathrm{Ni}$ & $\mathrm{Mn}$ & $\mathrm{Zn}$ & $\mathrm{Cd}$ \\
\hline 0 & 0 & 0 & 0 & 0 & 0 \\
\hline 2.5 & 951 & 787 & 885 & 208 & -0.2 \\
\hline 5 & 1701 & 1181 & 1348 & 274 & -0.4 \\
\hline 7.5 & 1950 & 1319 & 1442 & 289 & -2 \\
\hline 10 & 2143 & 1371 & 1817 & 302 & -2.2 \\
\hline 12.5 & 2191 & 1395 & 1954 & 311 & -2.6 \\
\hline
\end{tabular}


Table 2: Heavy metals adsorption capacity of Tadjan River suspended matters in different concentration of metals in river water ( $\mathrm{mg}$ of metal $/ \mathrm{kg}$ of suspended matter)

\begin{tabular}{|cccccc|}
\hline $\begin{array}{l}\text { Initial metal } \\
\text { concentration } \\
\text { in water }\end{array}$ & $\mathrm{Cu}$ & $\mathrm{Ni}$ & $\mathrm{Mn}$ & $\mathrm{Zn}$ & $\mathrm{Cd}$ \\
\hline 0 & 0 & 0 & 0 & 0 & 0 \\
\hline 2.5 & 685 & 787 & 922 & 197 & -1.7 \\
\hline 5 & 1272 & 1181 & 1320 & 272 & 0.1 \\
\hline 7.5 & 1954 & 1360 & 951 & 286 & -0.6 \\
\hline 10 & 2035 & 1431 & 1101 & 298 & -1.7 \\
\hline 12.5 & 2082 & 1480 & 1125 & 305 & -1 \\
\hline
\end{tabular}

The maximal adsorption capacity of metals by sediments and suspended matters in the river are in the following order: $\{$ [sediments: $\mathrm{Cu}(2200 \mathrm{mg} / \mathrm{kg})>\mathrm{Mn}(2000 \mathrm{mg} / \mathrm{kg})>\mathrm{Ni}(1400$ $\mathrm{mg} / \mathrm{kg})>\mathrm{Zn}(320 \mathrm{mg} / \mathrm{kg})$ ] [suspended matters: $\mathrm{Cu}(2100 \mathrm{mg} / \mathrm{kg})>\mathrm{Ni}(1500 \mathrm{mg} / \mathrm{kg})>\mathrm{Mn}(1200$ $\mathrm{mg} / \mathrm{kg})>\mathrm{Zn}(310 \mathrm{mg} / \mathrm{kg})]\}$. This is clearly evident of high capacity of sediments and suspended particulate matters in adsorbing dissolved metals. These results are in accordance with data provided by Forstner and Wittman (1981); Hart (1982); Lin and Chen (1998); and Karbassi (1989). Sholkovitz and Copland (1981) have discussed about solubility properties of $\mathrm{Fe}, \mathrm{Mn}, \mathrm{Cu}, \mathrm{Ni}, \mathrm{Cd}$ and $\mathrm{Co}$ in relation with humic acids in river waters. They found almost a similar trend of adsorption for $\mathrm{Cd}$. Experimental results can be fitted by polynomials of fourth and fifth order in sediments and suspended matters respectively (Figure 4).

\section{Discussion and Conclusion}

Increasing the adsorption capacity both in sediments and suspended matters in terms of initial concentration of the metal follows a fourth degree polynomial that are presented in table 3 for metals. Determination of $\mathrm{Cd}$ concentrations in sediments and suspended matters after adding different concentrations of other heavy metals ( $\mathrm{Mn}, \mathrm{Ni}, \mathrm{Cu}$ and $\mathrm{Zn}$ ) to the mixtures revealed that $\mathrm{Cd}$ would be desorbed from sediments and suspended matters whilst other metals concentration increase and they are being adsorbed onto the particulate phase (Figure 4).

It seems that environmental risk of dissolved $\mathrm{Cd}$ in the river is considerable and in addition to the usual factors of affecting adsorption and removal of $\mathrm{Cd}$ from particulate phase to dissolved phase (i.e. lowering $\mathrm{pH}$ ) increasing concentrations of other metals that may be originated from municipal, agricultural and industrial sources would affect the dissolution of $\mathrm{Cd}$ from sediments and suspended matters. Adsorption of $\mathrm{Cd}$ may occur because of replacement of $\mathrm{Cd}$ by other high concentrated metals.

Metals adsorption capacity of sediments and suspended matters of the Tadjan River (southern Caspian Sea) in relation to concentration of metals in the river water was investigated. The maximum metals adsorption capacity was in the following order: $\{$ [sediments: $\mathrm{Cu} \quad(2200 \mathrm{mg} / \mathrm{kg})>\mathrm{Mn} \quad(2000$ $\mathrm{mg} / \mathrm{kg})>\mathrm{Ni} \quad(1400 \mathrm{mg} / \mathrm{kg})>\mathrm{Zn} \quad(320 \mathrm{mg} / \mathrm{kg})]$ [suspended matters: $\mathrm{Cu}(2100 \mathrm{mg} / \mathrm{kg})>\mathrm{Ni}$ $(1500 \mathrm{mg} / \mathrm{kg})>\mathrm{Mn} \quad(1200 \quad \mathrm{mg} / \mathrm{kg})>\mathrm{Zn}$ $(310 \mathrm{mg} / \mathrm{kg})]\}$. Cadmium concentration in the sediments and suspended matters revealed that higher concentration of other metals (Mn, Ni, $\mathrm{Cu}, \mathrm{Zn}$ ) might cause adsorption of $\mathrm{Cd}$ from particulate phase. Adsorption and desorption trends and patterns in terms of metals concentration in river water follows polynomial equations. The result of present investigation clearly shows potential of reverine suspended particulate matter and bottom sediments in adsorbing dissolved metals that may occur during accidental spills.

\section{Acknowledgements}

Authors' wishes to thank Dr. N. Mehrdadi for his invaluable help during sample collections. Dr. Gh. Nabi efforts in determining heavy metal concentrations are appreciated. 

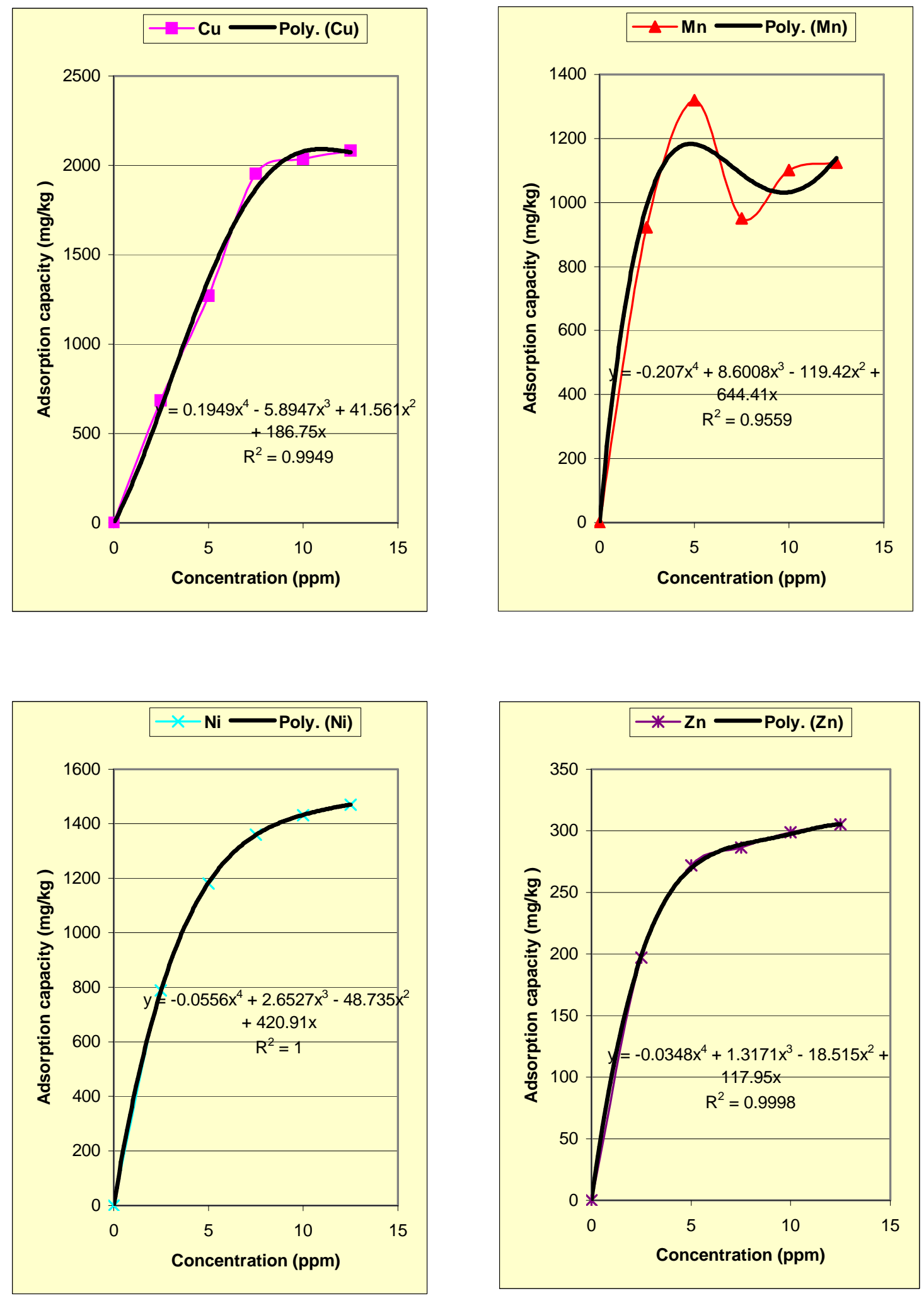

Figure 2: Heavy metals adsorption capacity by suspended matter of the Tadjan River in relation with initial metals concentrations in river water 

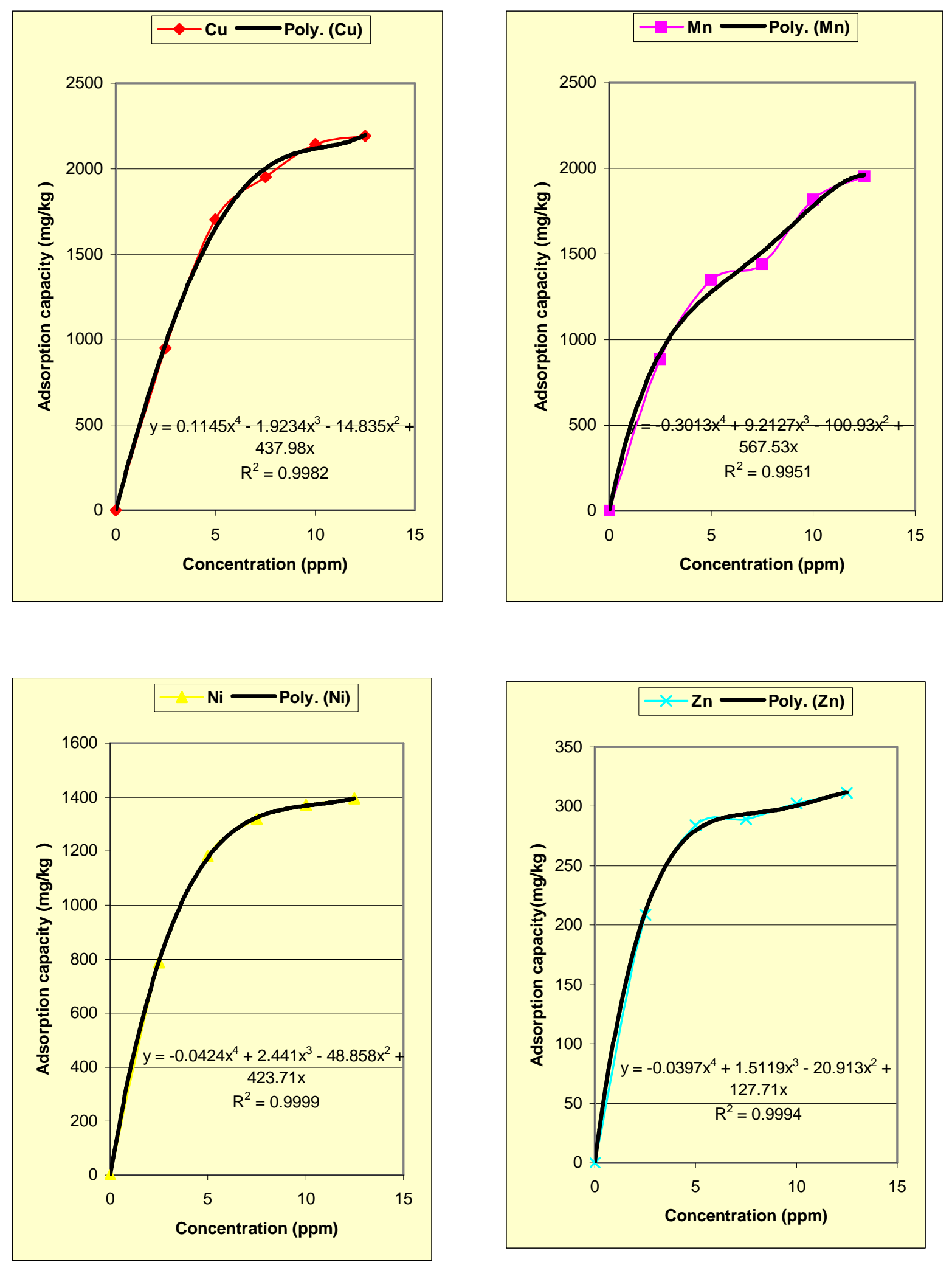

Figure 3: Heavy metals adsorption capacity by sediment of the Tadjan River in relation with initial metals concentrations in river water 

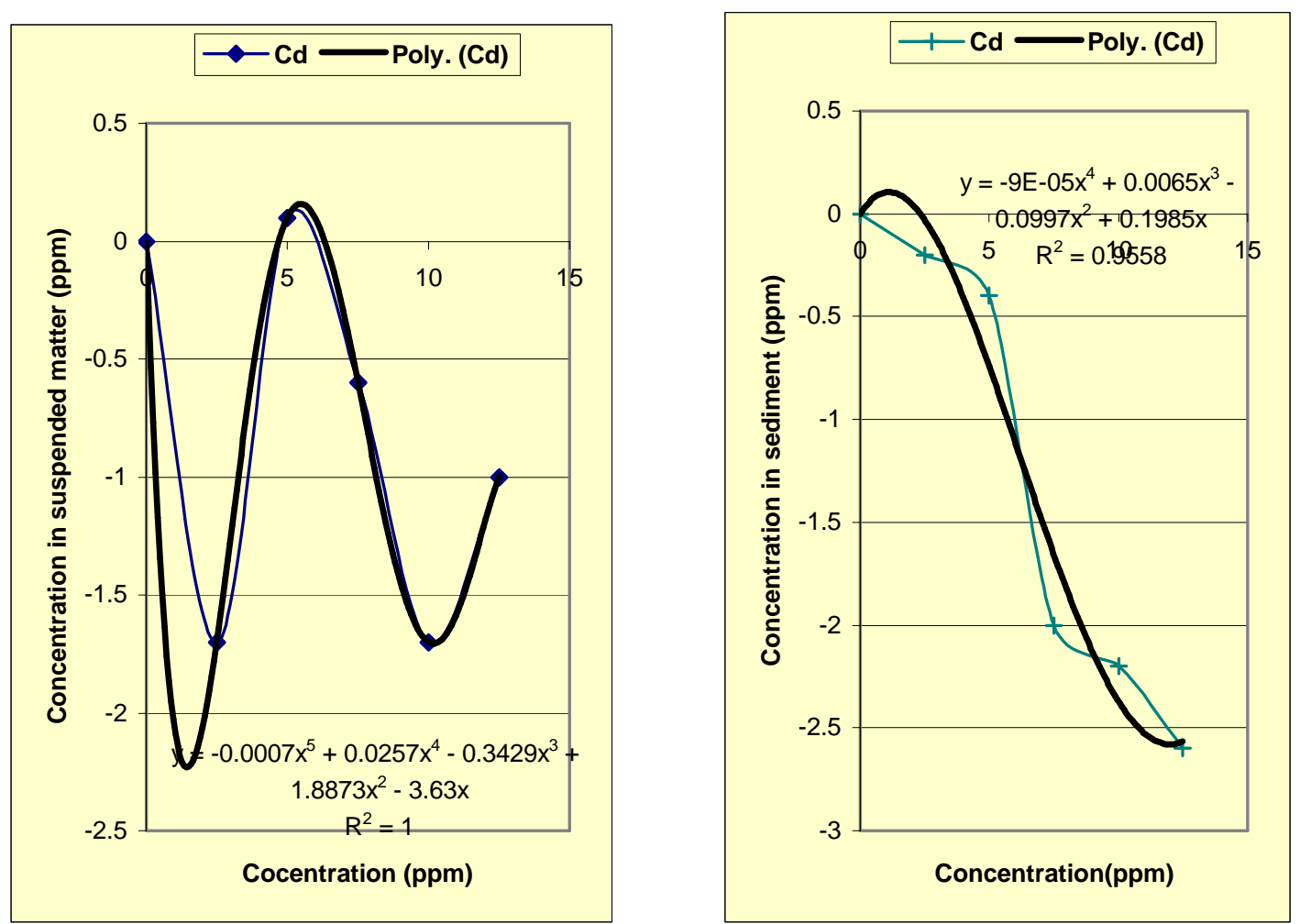

Figure 4: Cadmium adsorption/adsorption behavior in sediments and suspended matters in relation with initial metals concentrations in river water

\section{References}

Benefield, L. D., J. F. Judkins, and B. L. Weand, Process chemistry for water and wastewater treatment. Prentice-Hall, 1982

Chapman, D., Water quality assessment. Chapman and Hall, London, 1992

Dojlido, J. R. and G. A. Best, Chemistry of water and water pollution. Ellis Horwood, 1993

Forstner, U. and G. T. W. Wittmann, Metal pollution in the aquatic environment. Berlin: Springer, 1981

Hart, B. T., Uptake of trace metals by sediments and suspended particulates: a review. Hydrobiologia, 91: 299-313, 1982

Karbassi, A. R., Geochemical and Magnetic Studies of Marine, Estuarine and Riverine Sediments. Mangalore University, India, 1989

Lin, J. G., and S. Y. Chen, The relationship between adsorption of heavy metal and organic matter in river sediments. Environment International, 24: 345-352, 1998
Rose, S., The heavy metal adsorption characteristics of Hawthorne formation sediments. Chemical Geology, 74: 365-370, 1989

Sholkovitz, E. R., and D. Copland, The coagulation, solubility and adsorption properties of $\mathrm{Fe}, \mathrm{Mn}, \mathrm{Cu}$, $\mathrm{Ni}, \mathrm{Cd}, \mathrm{Co}$ and humic acids in a river water. Geochim Cosmochim Acta, 45: 181-189, 1981

U.S. EPA, Test methods for evaluating solid wastes. $S W-846,1990$

U.S. EPA., Methods for the determination of metals in environmental samples. EPA-600/4-91/010, 1991

Zhou, X. D., and S. C., Kot, Heavy metals ion adsorption on sediments of the Weiho and Hanjiang rivers. China, J., Environmental Hydrology, 3: 125 132, 1995 